\title{
Mitigating the Risks of Resource Extraction for Industrial Actors and Northern Indigenous Peoples
}

\author{
Alexis Monique Lerner ${ }^{\star}$, \\ The University of Toronto, Department of Political Science, Canada, and \\ Stanford University, Stanford US-Russia Forum Director of Research, \\ United States \\ Victoria Koshurina, \\ National Research University - Higher School of Economics, Department of Sociology, \\ Russian Federation \\ Olga Chistanova,
}

Khakas State University, Institute of History and Law,

Russian Federation

Angela Wheeler,

Harvard University, Department of Architecture, United States

\begin{abstract}
A collaborative relationship between native peoples and industrial corporations-two actors that value resource-rich land-is of vital importance for both the United States and the Russian Federation. A strong partnership between industrial and indigenous actors can help to ensure not only the stability of extractive projects, but also the protection of indigenous groups from the potentially existential threats associated with territorial loss. Cooperation between these two parties gains urgency as extractive corporations begin to explore the Arctic, a region of the world already home to over two dozen unique indigenous communities. In both the United States and the Russian Federation, there are legal precedents for negotiations regarding indigenous rights, natural resources, and the fuel-energy complex. Even so, parties involved in the extractive process frequently stray from these national and international legal guidelines. Our paper seeks to answer the question: why might rational actors-here, indigenous and industrial communities that are motivated by their preferences-fail to cooperate on extractive projects, even when robust collaborative agreements benefit all sides? We suggest that the explanation is twofold: first, indigenous land rights lack the consistency which may give indigenous communities control over their resources and cultural preservation; and second, a neutral and objective third-party mediator-whether in the form of a state or an international body-is often silent in, or absent from, the negotiation process, thereby undermining its authority to ensure fair and reasonable deliberations. Our findings can offer important insights for community-corporate relations, not only in the Arctic, but worldwide.
\end{abstract}

^Correspondence to: Alexis Monique Lerner, The University of Toronto, Department of Political Science, Canada, and Stanford University, Stanford US-Russia Forum Director of Research, United States. Email: lerner.alexis.m@gmail.com 
Keywords: Natural Resources; Oil and Gas; Extraction; Indigenous; UNDRIP; Negotiations; Arctic

Responsible Editor: Øyvind Ravna, UiT - The Arctic University of Norway, Tromsø, Norway.

Received: January 2017; Accepted: April 2017; Published: May 2017

\section{Irreconcilable ideals and power politics ${ }^{1}$}

Sergey Kechimov, 57, is the guardian of Lake Imlor, a sacred Surgut Khanty site located within the Russian Federation's Khanty-Mansiysk Autonomous Region and the Fedorovka oil field. Native groups protect communal areas like Lake Imlor for ceremonial and spiritual purposes; in these Territories of Traditional Nature Use (TTNU), fishing, hunting, and the keeping of dogs are religiously prohibited activities. ${ }^{2}$ Meanwhile, Surgutneftegas, the oil company fighting for use of the indigenous land, claims that one million tons of oil lie beneath the tribal area. ${ }^{3}$ As Surgutneftegas extraction projects circle closer and closer around Lake Imlor, they pollute the air, intoxicate waterways, and carry fire hazards, threatening the safety and quality of life for the area's remaining Khanty community.

Surviving on this native land in the middle of the Fedorovka oil field seems almost impossible for both reindeer and the Khanty people that herd them-the wood is impoverished, the moss is gone, and the little remaining pasture has long since been pressed to the ground by the wheels of vehicles crossing to and from extraction sites. With their land under threat and alternative job prospects negligible, the Khanty people have largely left Lake Imlor. And yet, Kechimov stays behind, claiming a sense of duty to protect the sacred site; a descendant of shamans, he refuses to betray his ancestors and their heritage.

In September 2014, after more than four years of ongoing confrontations with oil executives, illegal poachers, and hostile workers, Kechimov shot a group of attacking dogs, which were originally brought to the area by oil workers. By January 2015, Surgutneftegas charged Kechimov with criminal assault, the terms of which were not made clear to Kechimov in his native language until his court hearing six months later in June 2015. Writes Maria Favorsky, a representative from the environmental advocacy group GreenPeace: "Locals see the charges as a blatant attempt by the oil industry to scare off indigenous opposition to oil drilling, and to get rid of a man who literally stood in its way." 5 According to Elena Sakirko, a campaigner for indigenous people with Greenpeace, Kechimov was convicted in the fall of 2016 of threatening to kill the rig workers. ${ }^{6}$ And while Kechimov circumvented a two-year prison sentence, Surgutneftegas continues to encircle Lake Imlor, posing a long-term threat to his community and way of life.

\section{Introduction}

The story of Sergey Kechimov and Surgutneftgas is not the first tale of failed cooperation on an extractive project; in fact, tensions between indigenous and 
industrial actors are common. We saw this quite recently in the forty-week long, violent standoff of 2016 between the Sioux Tribe at Standing Rock and representatives of the Dakota Access Pipeline, restarted in 2017 in reaction to US President Donald Trump's Executive Order on the Keystone XL Pipeline. Assuming that extractive projects will continue to take place-at least until the development of clean energy technology-, designing an enforceable path for partnership is ever vital. Robust and reliable negotiations between industrial and indigenous actors can help to ensure not only the stability of extractive projects, but also the protection of indigenous groups from existential threats associated with territorial loss. While international and domestic law provide precedent for cooperation, parties involved in the extractive process frequently stray from these institutional guidelines, inevitably resulting in negative consequences that vary from unbalanced negotiations to escalated violence.

Many historic lands occupied by indigenous communities contain vast reserves of oil and natural gas. ${ }^{7}$ Furthermore, the indigenous peoples living on resource-rich land are sometimes expected to bear the environmental costs of extraction without adequate compensation or comprehensive global protections. ${ }^{8}$ As industrial actors continue to expand their role in resource-rich territories, it is important that states and international organizations establish stronger-and reinforce existing-incentives for preliminary negotiations and corporate responsibility initiatives. ${ }^{9}$ Over the last five years, research on industry-indigenous relations has increased substantially, an indication of the growing importance of integrating human rights protections into extractive projects. ${ }^{10}$ This begs the following question: How can powerful actors and at-risk minorities share natural resources with minimal negative consequences? Specifically, we are interested in how industrial actors affiliated with two major northern powers-the United States and the Russian Federation-can establish shared best practices in indigenous relations as they expand their resource extraction industries in Alaska, Siberia, and the Arctic.

This project is built on three assumptions: first, extractive processes will take place as long as a global demand exists; second, industrial actors want to avoid costly legal battles and public relations problems; and third, indigenous actors desire protection from existential threats and compensation for losses. ${ }^{11}$ Presumably, both parties want to mitigate the likelihood or severity of these potential extractive risks. ${ }^{12}$ Some industrial actors, such as the oil companies Chevron and Rosneft, do this by offering financial benefits to indigenous communities or by incorporating indigenous leaders as extractive consultants. ${ }^{13}$ However, despite the likelihood that discontent can lead to protests, property damage, or physical violence, many extractive processes continue to operate without effective indigenous integration. ${ }^{14} \mathrm{With}$ the understanding that preliminary negotiations are effective in mitigating risk, why do international organizations and states vary in their tendency to incorporate indigenous players in extractive operations?

Indeed, much of the current literature approaches resource extraction in indigenous lands as a zero-sum game, where only the industrial or indigenous actor 'wins' ${ }^{15}$ This binary between winner and loser results in a scholarly gap as it ignores some potential areas for cooperation. Thus, our research question asks: is there a 


\section{A.M. Lerner et al.}

possible extractive scenario where all actors cooperate to improve their overall gains? We hypothesize that enforceable preliminary negotiations, supervised by a neutral and objective third party, will lead to smoother and lower-cost extractive operations because they mitigate potential post-extraction risks. This coincides with traditional collective action theory, which suggests that a third party is necessary in mitigating conflicts, enforcing agreements, and imposing sanctions. ${ }^{16}$

The goal of this paper is to understand better the puzzle of preliminary negotiations on resource extractive projects and, in particular, the factors present when they operate most effectively. We suggest that neutral mediators and state institutions designed to ensure credible commitments are a preferable, and often necessary means of reaching successful agreements. Our paper is organized as follows: first, we explore the existing literature on negotiations and determine the unique characteristics of indigenous-industrial negotiations, namely the universe of actors, interests, and intervenors that may be involved. Next, we offer some background on our cases-the United States and the Russian Federation. We start with a legal and socio-political overview of industry-indigenous relations in the two countries before delving into our particular cases. In order to bring a methodological consistency to this project, we conduct a four-pronged comparison of industry-indigenous relations on extractive projects in Alaska, the American Southwest, the Russian Far East, and in Siberia.

We chose to conduct a comparative analysis of the United States and Russia because of their many similarities-regional hegemonic status, demographic makeup, conservative national culture, overall landmass, Arctic territory, natural resources, and the characteristics of their indigenous populations. While there are some legal and socio-political differences, we argue that conflicts between indigenous and industrial actors on issues related to resource extraction are problematic in similar ways in both cases. We conclude our paper with an analysis section that highlights instances when legislation or norms promoted by a third-party helped or hindered peaceful negotiations between the indigenous and industrial actors. Throughout the paper, we rely on first-hand interviews with experts and community leaders, existing legislation, press regarding legal proceedings, and scholarly literature.

Uncovering best practices for industrial-indigenous relations is important; enforceable preliminary negotiations could protect indigenous actors against heritage loss and corporate actors from legitimacy problems. As we hope to show in this article, the possibilities for comparative study on this topic are vast and largely unexplored. This is a critical and timely puzzle for the global north as it balances the quest for energy and natural resources with at-risk, resource-based indigenous minorities. Furthermore, this research on industry-indigenous relations can be applied far beyond these particular actors. Indeed, this project could also offer insights into the power dynamics of cooperation between unequal partners across temporal and spatial planes.

\section{Why negotiate?}

In order to determine the benefits of preliminary agreements on extraction projects, we seek to first define the actors, interests, and traditional institutions-or systems of 
rules that govern behavior in the negotiation process-involved. ${ }^{17}$ We define the negotiation process as the series of discussions regarding an adversarial scenario, in which two or more actors with unique interests attempt to reach an agreement. By evaluating barriers and assessing room for cooperation, the negotiation process can help to address competing party interests and ethical concerns, while maximizing joint value. ${ }^{18}$

In order to achieve successful negotiations, actors must define their terms-what are they willing to sacrifice and for what are they willing to fight? By clearly delineating interests and expectations, parties can hope to overcome legal stalemate. However, barriers inevitably remain: for one, actors are responsible to their constituencies, which may be divided on how to determine interests and sacrifices. Furthermore, actors may engage in secrecy or deception, which could result in façade negotiations (in which one or more party does not intend to follow through with the agreed-upon result of the proceedings). Last, actors may hold unequal power in the negotiation proceedings, due to variation in funds available, political connections, or legal precedent. ${ }^{19}$ Under these conditions of unequal negotiation, a weaker actor can strengthen their side by redefining their capacity (for example, by bargaining formally and collectively, instead of informally and individually), by setting hard deadlines, and by worsening the consequences of a refused offer for the other actor(s). ${ }^{20}$ It should be noted that threats intended to encourage the stronger party to negotiate in good faith can backfire, resulting in retaliation from the opposing side and heightened overall costs. Last, these proceedings can become intractable when actors hold competing interests or definitions regarding the sacred, which can reference tangible claims - for example, the indivisibility of ancestral waterways-or intangible claims, such as those related to primordialism. ${ }^{21}$ Following Howard Raiffa's logic in his book The Art and Science of Negotiation, we use the following section to walk through the negotiation process on resource extraction projects, outlining the universe of potential actors, interests, and intervenors. ${ }^{22}$

The first player in such a bargaining agreement is the industrial, or firm-based, actor. Arguably, industrial actors are positioned to gain the most benefit from the extractive process, regardless of whether they engage the indigenous partner. The potential gains are predominantly financial, as the industrial actor not only increases revenue with each additional extraction project, but also positions itself ahead of its competition with the discovery of each new site. And yet, industrial actors have many avenues of potential loss in these scenarios, such as potentially violent protests in the name of land rights, cultural destruction, and environmental devastation. Protests could lead to financial costs in site equipment repairs, delayed extractions, and the loss of life. Furthermore, oil spills could destroy water systems and wildlife habitats not just for residents near the extraction site, but potentially for all those whose waterways produce markets and food sources tangentially connected with the site. If not handled in a timely and thorough manner, these immediate concerns could cause significant harm to industrial actors on an international stage. Public relations scandals could result in severed contracts, expensive and lengthy legal battles, and a subsequent market drop. 


\section{A.M. Lerner et al.}

The second actor involved in extraction processes is the local, aggregated community. Here, we understand the local community as indigenous to the land, particularly in cases of geographically isolated extraction. It is possible, however, that a local community may be composed of non-indigenous citizens, or some combination thereof, commonly present in cases of inland extraction. Despite this understanding, we use this opportunity to focus on indigenous actors in these preliminary negotiation processes.

Assuming that the termination of an extractive plan is an unlikely outcome, potential bargaining gains for indigenous actors vary. At most, an indigenous actor may gain a desirable and balanced agreement that includes structural accommodations for spiritual sites or adequate compensation in exchange for permitted land-use (even so, some indigenous communities may find no amount of compensation acceptable for extractive activities that result in permanent changes to their landscapes and livelihoods). At the very least, the indigenous community may gain visibility by aggregating their interests through the use of collective representation. Between these poles exists a plethora of financial, emotional, and political degrees of support. For the indigenous community, a failure to organize or negotiate may result in a complete disregard for their preferences. The possible consequences of this failure include forced displacement, assimilation, loss of land, loss of language, and loss of culture. Surely, for the indigenous community, it appears to be more beneficial to negotiate than to stay silent.

Finally, the third actor present in industry-indigenous relations is the state or, less frequently, an international mediator. Mediators, when monitoring negotiations in good faith, can play a largely positive role. First, they can prevent tensions from escalating as their participation encourages negotiating actors to "at least appear to be reasonable." 23 This may result in greater respect for the negotiation process, including its deadlines and enforcement. Second, a mediator can help parties find equal footing in negotiation proceedings by carving out time for each party to state their case, by reframing interests in nonthreatening terms, and, in theory, by helping both parties conclude with an equitable arrangement.

Of course, mediation can turn sour; mediators can maintain their own interests, pick sides, or engage in secret talks with actors that parallel the formal negotiations. Finding an ethical and neutral negotiator on issues related to resource extraction can be particularly difficult. For example, a state may gain revenue from successful extractions or its politicians may reap public approval if extractive projects boost employment rates, and therefore the state could share interests with a particular actor. Indeed, in the Russian Federation, for example, many large oil and gas companies are public, or stateowned, corporations. In these scenarios, the state maintains many of the same benefits and costs as the industrial actor: successful negotiations lead to financial rewards and failed negotiations can beget protests and vandalism.

The difference between industrial actors and the state is the degree to which they can circumvent restrictions. An industrial actor, finding barriers to business within a particular state, could well refuse to conduct operations in said state in the future. However, the state is uniquely aware of a need for sustainability in its actions - the threat of popular uprising, which could result in electoral defeat, may be incentive 
enough to demand that actors engage in fair negotiations. Likewise, international public relations crises could damage states if they result in economic sanctions from the international community. In short, the costs, while similar, are ultimately heightened for the state actor. Therefore, we argue that while industrial actors generally focus on mitigating short-term risks, the state maintains an interest in establishing strong institutions that can reduce long-term risk.

Assuming that each of these actors are rational, in that they learn from previous interactions, process new information, rank their preferences, and act in order to mitigate potential costs, it appears that each of these three actors benefits from participating in, and maintaining, preliminary negotiations on extraction projects. Consider the following simulated situation in which a negotiation between industrial and indigenous actors takes place. A tribe has lived on a one-hundredacre plot of land for twelve generations. Not only is the land a spiritual center for the community, but it also serves as an avenue of sustainability for the tribe's hunters and gatherers. Families drink from local water sources and flocks of animals feed freely in the wide expanses. Meanwhile, representatives from Exxon Oil discover reserves of natural resources-oil and gas-in the region around the tribal lands and feel confident that reserves exist on the indigenous land, as well. Exxon Oil knows that new oil reserves help to flood the market and lower domestic oil prices, which in turn lowers the costs of plastics, manufacturing, and transportation. Meanwhile, state interests rest divided: on the one hand, the state is eager to use domestic resources over contentious overseas supplies on economic, national defense, and moral grounds; on the other hand, the state maintains an interest in preventing the domestic unrest from threatened minority groups or negative publicity for perceived human rights violations. When interests diverge like this, how can conflict be mitigated?

Surely, the indigenous interest of preservation-quite literally, funding their dayto-day lives through hunting and gathering-can be supplemented with monies provided by Exxon Oil. However, while this sudden change in income may open new avenues for different kinds of labor, it may also potentially lead to new problems: diets of heavily processed foods, substance abuse, and benefit addictions. Even if Exxon Oil compensates the indigenous community for the extractive use of its land, no cash payment can replace a destroyed sacred space. In addition, Exxon Oil must allot funds for emergency spill and public relations management. These defense measures can become exceedingly expensive. Finally, the state's position remains precarious, as a negative situation, such as a civilian death or an oil spill, may reflect poorly not only on the industrial actor, but on the state and its leadership as well. By permitting an industrial actor to operate without consequence within its borders, the state takes on a portion of the potential rewards, but also the liability. Therefore, it is in the state's interest, as much as the industrial actor's interest, for the extractive process to go as smoothly as possible.

It is possible, as a counter-factual, that preliminary negotiations do not result in mitigated risk for actors on both sides of the bargaining agreement. The very act of bargaining implies a certain willingness on the part of the indigenous community to 


\section{A.M. Lerner et al.}

cooperate with industrial actors by sacrificing their land in exchange for material benefits, whether from a position of dominance, as in the case of the semi-sovereign Northern Ute, or from a position of weakness, as in the case of Alaskan nations before the seemingly inevitable expansion of the oil pipeline. Is it possible that, for the indigenous actor, greater benefit lies in refusing to negotiate with industrial actors? So, too, for industrial actors: negotiations may result in up-front inconveniences that fail to outweigh the potential long-term costs of extractive projects. After all, it is possible that protests, vandalism, death, safety mishaps, and environmental crises will never actually take place. Therefore, it is possible to assume that the industrial actor takes a greater risk by participating in preliminary negotiations than in evading them.

Overall, we argue that the state and the industrial actor hold the upper hand in negotiations regarding resource extraction on land traditionally occupied by native peoples, while the indigenous community remains relatively weak. In some cases, this asymmetry is mitigated by the latter's ability to organize collectively; however, even in the case of collective bargaining, we suggest that a neutral arbiter is requisite in ensuring that enforceable negotiations are conducted fairly between unequal actors. Therefore, the best way to avoid a potential existential threat for the latter is to give governing authority to the state or to an international commission with the ability to enforce agreements domestically. In the case of industryindigenous conflict, in particular, mediators can level an asymmetrical negotiation by establishing indigenous leaders as de facto veto-power extractive consultants so that these communities can share the burden of conducting a safe and efficient operation.

It is important to note that while an extractive project is ostensibly its own bargaining game with unique participating actors, these actors could feasibly be involved in other games with other unique actors. For example, in the scenario outlined above, Exxon Oil could be involved in preliminary negotiations with a coalition of indigenous leaders in Alaska as well as native leadership in the southwestern United States. On the one hand, it is possible that the industrial actor in this scenario will learn from the other scenario in real time, but it is also possible that actors involved in multiple games understand how to rank the gravity of each game and even how to play opposing actors off one another. Firm-based actors may also have private arrangements with national actors, compromising the autonomy of both parties. The possibility of multiple under-the-table agreements not subject to transparent public review complicates the potential outcome and benefit of preliminary negotiations.

\section{Cases: United States and Russian Federation}

To investigate this puzzle of preliminary negotiations, we highlight extractive projects in both the United States and the Russian Federation. ${ }^{24}$ We chose these two countries as they are global superpowers with substantial territory in the Arctic region. We also considered the value in positioning the US and Russian cases side-by-side to 
demonstrate a shared puzzle in a temporal moment in history when the two countries appear to be diametrically opposed in all matters of domestic and foreign policy. In future expansions on this project, it will certainly be valuable to include other cases relevant to the global north, including Canada and Scandinavia.

In this section of our paper, we present a descriptive summary of our findings, divided between the inland and remote regions of each country. We chose to divide our cases in this manner in order to ensure an expansive breadth of existing cases, and a deeper understanding of each of our four designated regions. In theory, the inland cases outline scenarios where industry-indigenous extractions take place in more population-dense regions, or in closer connection with urban centers. We suggest that these cases may be affected by established political institutions, frequent monitoring, and networks of roads. Alternatively, we also compare two remote regions that are geographically or physically separate from major urban centers and political oversight. We chose to alternate between these regions in an effort to demonstrate a variety of industry-indigenous relations in these two states.

We begin this section with an evaluation of the legal and socio-political background of industry-indigenous relations in the United States and Russia. We then present detailed case studies of negotiations in our chosen cases. We close this section, and the paper, with an examination of how our findings may influence policy-making in both the United States and in the Russian Federation as both move toward the new, Arctic arena.

\subsection{Legal background on industry-indigenous relations in the US and Russia}

Today, indigenous peoples of the world and their ancestral land are in danger of alienation and cultural extinction because of the triple-threat of climate change, assimilation, and destructive extraction industries. Some pieces of international legislation attempt to shield indigenous communities and lands from these threats, such as the momentous United Nations Declaration on the Rights of Indigenous Peoples (UNDRIP) of September 2007, which seeks to protect individual and collective indigenous rights. The UNDRIP, an international agreement that took nearly twenty-five years to design, has garnered different reactions from global powers. Indeed, neither Russia nor the United States initially supported the declaration, allegedly on the grounds that support for the declaration could undermine their own sovereignty during land and natural resource disputes. ${ }^{25}$

Three years after the introduction of UNDRIP, in December 2010 and in response to pressure by domestic indigenous groups, President Barack Obama announced America's endorsement of the legislation. ${ }^{26}$ And yet, indigenous peoples were not reassured by the lukewarm nature of the following caveat: "The United States understands [the importance of a] call for a process of meaningful consultation with tribal leaders, but not necessarily the agreement of those leaders, before the actions addressed in those consultations are taken." 27 In short, the Obama administration made it clear that endorsement of the UNDRIP was not legally binding for negotiations that started prior to December $2010 .^{28}$ 


\section{A.M. Lerner et al.}

The Russian Federation continues to abstain from the UNDRIP. The official position of the Kremlin regarding the UNDRIP is that some of its provisions do not satisfy Russian interests. ${ }^{29}$ In the oil-and-gas-rich Russian Federation, a domestic legal framework regulates the relationship between the indigenous peoples and extractive companies. It stipulates that negotiations must occur in concordance with the Russian Constitution, which "guarantees the rights of indigenous peoples in accordance with the generally recognized principles and norms of international law and international treaties ratified by the Russian Federation." ${ }^{30}$ Furthermore, Russia has regional legislation that governs industry-indigenous relations on a local level.

It should be noted that the definition of indigenous is different in the United States and the Russian Federation. Native Americans, Indians, or the category of Indigenous Peoples in the United States refers to nations or tribes that pre-dated the European colonization of the Americas. In Russia, identity politics are somewhat more complicated. National minorities that are formally recognized, such as Tatars, gained their minority status during Soviet rule. Titular minorities such as these benefit from substantial rights, ranging from autonomous regional control to the right to teach indigenous languages in regional primary schools. It is unfortunate that for many indigenous minorities in Russia, federal legislation has a 50,000 person cut-off. In practice, this means a group may be recognized as a small-in-number minority, but it does not have access to collective or land rights in the way that a titular group might. There have been numerous attempts since 1999 to design a comprehensive policy to better-define indigenous peoples in Russia (Federal Law 82-FZ, Article 3, for example). Due to this legal gap, non-governmental organizations like the Russian Association of Indigenous Peoples of the North (RAIPON) serve a critical role in assisting the indigenous community against industrial exploitation. ${ }^{31}$

\subsection{Socio-political background on industry-indigenous relations in the US and Russia}

Domestically, the Russian Association of Indigenous Peoples of the North (RAIPON) is particularly active in mediating conflicts between oil and gas companies and the indigenous community. Founded in 1990 at the First Congress of Indigenous People of the North USSR, RAIPON is a non-governmental organization (NGO) that organizes rights-based legal and legislature advocacy for approximately 270,000 individuals from 41 indigenous groups across Russia. ${ }^{32}$ In particular, RAIPON aids in domestic and international mediation, publishes various newsletters on indigenous issues, operates a youth empowerment wing, and trains members of the indigenous community in legal literacy (for example, how to survey indigenous land to determine damage costs after extractive projects while complying with federal and regional guidelines). ${ }^{33}$ In 2008, the United Nations Committee on the Elimination of Racial Discrimination (CERN) requested that the Russian state make efforts to draw its domestic treatment of its indigenous population in line with UNDRIP, particularly regarding land rights, access to hunting and fishing resources, compensation, and political representation. ${ }^{34}$ 
While Russia originally agreed to CERN's suggestions, the state did not follow through. Thus, in the early summer of 2012, RAIPON, together with the International Work Group for Indigenous Affairs (IWGIA) and the Institute for Ecology and Action Anthropology (INFOE) submitted a review proposal to the Human Rights Council, requesting that they pressure the Russian state to follow through on their agreement with CERN and implement the promises of Federal Law 82-FZ (1999), entitling indigenous communities to compensation for land damage. ${ }^{35}$ Subsequently, when the Russian Ministry of Justice ordered the forced closure of the NGO with Resolution 2332-r in 2012, RAIPON's Vice President, Dmitry Berezhkov, publicly suggested that the state attacked the organization for the latter's criticisms regarding natural resource exploitation. ${ }^{36}$ As an organization that prioritizes land rights for indigenous peoples in the oil-rich state, Berezhkov's argument is not necessarily new: indigenous people are legally permitted to hunt and fish on their ancestral land, even if this land is federally owned. However, because of RAIPON's trans-national partners and their membership in various international organizations-from the Arctic Council to the United Nations Economic and Social Council-it is possible that the Russian state perceived them as a strong, vocal, and even foreign-backed threat. Indeed, in February 2013, while RAIPON remained under forced closure, the Russian state signed an extractive agreement with Exxon Mobil Corp and Rosneft that would give the two oil and gas monoliths access to the country's Arctic region. ${ }^{37}$

In March 2013, a restructured RAIPON emerged with new leadership at its helm, along with public acknowledgement of the merits of a self-sufficient policy regarding energy security. ${ }^{38}$ Current RAIPON President, Grigoriy Ledkov, also serves the State Duma of the Federal Assembly as a bureaucrat on indigenous rights. In particular, Mr. Ledkov acts as both the Chair of the Duma Working Group for Nationality Issues and the Head of the Permanent Delegation of the State Duma to the Nordic Council. ${ }^{39}$ However, it appears that RAIPON, its leadership, and the indigenous advocacy community in Russia remained on the Ministry of Justice's radar. A year later, in September 2014, a group of indigenous-rights activists, including former-RAIPON Vice President Pavel Sulyandziga, had their passports seized en route to the United Nations World Conference on Indigenous Peoples. ${ }^{40}$ In an interview, Sulyandziga accused state security of holding the team over their loud opinions regarding resource exploitation and land rights in Siberia and the Arctic. ${ }^{41}$ State restrictions on indigenous-rights advocacy have since expanded. In early 2016, the Ministry of Justice declared the International Development Fund for Indigenous Peoples of the North, Siberia, and the Far East 'Batani' to be a foreign agent under the November 2012 Foreign Agent Law, 121-FZ. The law prohibits organizations from using foreign aid to pressure Russia domestically. Weeks later, the Center for Support of Indigenous Peoples of the North, an organization run by Pavel Sulyandziga's brother, Rodion, also ran into legal troubles per 121-FZ. ${ }^{42}$

Geopolitics also play a role in a state's decision to adopt the UNDRIP. For example, in 2012, the international community used its networks and influence 


\section{A.M. Lerner et al.}

to overrule the shutdown of RAIPON, a clear affront to national sovereignty. Perhaps in response, in December 2015, the Russian Federation decreed that domestic law would trump an international law or ruling. ${ }^{43}$ However, legal scholars like Ruslan Garipov suggest that this passed in response to the European Court of Human Rights as opposed to international declarations such as the UNDRIP, and that Russia will continue to adhere to international institutions like the latter. ${ }^{44}$ Despite potential threats to state sovereignty, a commitment to multilateral legislation demonstrates to the international community that a state is willing to make a credible commitment to upholding a particular law or norm. This credible commitment is valuable not only to the domestic population that it concerns, but also to the maintenance of stability in a sometimes-chaotic international community.

In the United States, alternatively, indigenous communities are permitted to organize politically for both domestic and international purposes. Indeed, indigenous communities hold pseudo-sovereignty, operating as domestic dependent nations with independent representation at the federal level. However, the US is still criticized for its treatment of its native minority. In 2012, an independent body from the UN Human Rights Council (UNHRC) declared that indigenous communities in America:

"Face significant challenges that are related to widespread historical wrongs, including broken treaties and acts of oppression, and misguided government policies, that ... manifest themselves ... [as] impediments to the exercise of their individual and collective rights." 45

And while present-day America cannot erase the nation's violent past, current leadership does attempt to right historical wrongs. In 2013, President Barak Obama increased the federal budget for indigenous affairs by three percent and members of the indigenous community continue to benefit from affirmative action programs at publicly funded state universities and in the public sector. ${ }^{46}$ Furthermore, the passing of the Affordable Healthcare Act and its proposed reconstruction in 2017 under President Donald Trump may offer new opportunities in healthcare coverage to members of the indigenous community. Even so, US Census statistics note that "a quarter of all Native Americans live in poverty" with "rates of alcoholism ... five times that of the rest of the US population." ${ }^{\prime 7}$ Combine these statistics with major political battles like the Keystone XL pipeline that runs through indigenous territory, oil spills in the Mississippi River or the Gulf of Mexico, and calls to return national sites to indigenous populations-like Mount Rushmore or a growing number of college campuses-and it becomes clear that the United States has a long way to go in meeting equitable standards for its indigenous peoples.

\subsubsection{Region one: Russian inland}

The Tyumen Region (including the Autonomous Regions of Khanty-Mansi and Yamalo-Nenets) is located largely in the southwestern part of Russia's 
West Siberian plain. The topography of western Siberia is unique, and traditional forms of farming in northern Tyumen remain of great cultural and economic importance. In fact, the world's largest herd of reindeer-over 700,000-can be found in the Yamalo-Nenets Autonomous District. Likewise, the heavily regulated $\mathrm{Ob}$ Basin in Yugra is home to over fifty species of rare fish.

In 1964, oil and gas were discovered in the area, which, in turn, has shaped the region's way of life and economic activity. Despite industrialization, many indigenous peoples of the north-Nenets, Khanty, Mansi, Selkups, and other groups-continue to live in Tyumen Region. The majority continue to practice the traditional, indigenous ways of life: herding and nomadism. Today, Tyumen Region is Russia's main source of oil and gas.

Nomadic peoples and the oil and gas industry each have their own, often contradictory, interests regarding this shared land. As a result, the state has actively intervened between these two actors through the establishment of various institutions that seek to protect both the heritage of indigenous groups and valuable state resources. For example, the Tyumen Industrial Institute (now the University of Oil and Gas) and the Institute for the Development of the North both work to find collaborative solutions regarding pollution, cultural infringement, and ecological preservation.

The state also works to integrate its indigenous population politically: for example, the Khanty-Mansi Autonomous District has its own parliament, in which three seats are allocated to indigenous representatives. In the Nenets Autonomous District, Yuri Hantazeysky, a representative of the Nenets People, holds the position of Deputy Governor and oversees issues relating to indigenous peoples. Furthermore, in 2011, a number of legislative provisions were adopted in Tyumen Region to protect the rights of its indigenous peoples, thereby protecting them from spatial reduction, granting them environmental sanctuaries, and giving them the opportunity to maintain control over sacred spaces. ${ }^{48}$

Most importantly, perhaps, companies involved in oil production in Western Siberia are legally required to cooperate with communities living near the oil fields. ${ }^{49}$ The effects of this obligation are largely positive. For example, Rosneft frequently hires indigenous hunters to protect extraction sites from wild animals, allots compensation for displaced people, and develops programs to facilitate cooperation between the company and local residents. ${ }^{50}$ In 2015, for example, Rosneft gave 39 million rubles to "support the traditional way of life and improve the living conditions of small indigenous peoples of the North." 51 From our interviews with company executives and indigenous leaders from the oil-rich, northern Tyumen Region, we understand this support to be not only in the form of resource-benefits (unlimited gasoline for personal use, extractive rents provided to residents in exchange for their compliance, and paid labor opportunities designed for native workers on extractive projects), but also indirect benefits such as funded schooling for area children and paid vacations for affected families. ${ }^{52}$ Indigenous interests appear to be relatively and largely protected by federal, regional, and local legislation in the oil-rich Tyumen Region. However, despite measures taken by the government and various organizations, the peaceful 


\section{A.M. Lerner et al.}

coexistence of indigenous peoples and oil companies is frequently violated-companies do not always effectively incorporate indigenous interests and actors into their extractive projects and, as we saw in the case of Sergey Kechimov, sometimes local actors fight back in violent ways.

\subsubsection{Region two: Remote Russia}

Sakhalin Region is one of the most remote regions of Russia. It is situated just off the east coast of Russia's mainland, to the north of Japan. Oil drilling on the island of Sakhalin began in the early 1990s. Extractive projects, called Sakhalin-1 and Sakhalin-2, were launched in 1994 and 1996, respectively, on the basis of a production-sharing agreement between the Sakhalin consortium of energy companies (including Shell, Mitsui, and Mitsubishi), the Sakhalin regional government, and the federal government. By the time both projects began to draw revenue in 1998, environmental advocacy began to gain popularity, attracting national and international organizations alike to Sakhalin Region.

In 2001, the Russian Association of Indigenous Peoples of Sakhalin Region (RAIPOSR) began to mobilize in order to promote indigenous rights on extractive projects. RAIPOSR's goal was to establish a partnership with the project operators ExxonLTD and the Sakhalin Energy Consortium. A cooperative agreement resulted between RAIPOSR and ExxonLTD. Indeed, since 2003, the president of the Russian Association of Indigenous Peoples of Sakhalin Region and the district representatives of indigenous peoples have sat on the Coordination Council of ExxonLTD. Unlike Exxon, the Sakhalin Consortium refused to sign a similar agreement with RAIPOSR, alleging that RAIPOSR was not an authorized representative of the interests of all the indigenous peoples of Sakhalin region.

Tensions between the oil industry and the indigenous communities of Russia worsened, resulting in the 'Green Wave' movement of January 2005, in which Nogliki residents blocked access roads to extraction sites, demanding a tête-à-tête with energy companies. By March, the indigenous community organized the new Regional Council of Authorized Representatives of Indigenous Peoples of Sakhalin Region. This council would lead the new round of trilateral dialogue between the indigenous people, the state administration, and energy companies. These talks resulted in the creation of the Sakhalin Indigenous Minorities Development Plan (SIMDP), a de facto peace treaty between Sakhalin Energy and Council representatives. The plan focused on funding educational, cultural, economic, and health-related initiatives in the indigenous community. ${ }^{53}$ In November 2010, the SIMDP was extended for the second phase of the plan (SIMDP-2), which included a budget of 1.56 million dollars for the five years from 2011-2015. Through SIMDP-2, the procedure for dealing with complaints about inflicted ecological or social harm became more transparent and systematic. Overall, SIMDP and SIMDP-2 demonstrate that it is, in fact, possible to create institutional mechanisms to allow a private company to engage constructively with communities and local authorities on an extractive process. 


\subsubsection{Region three: Continental US}

The continental United States is no stranger to negotiations regarding land and natural resources. This geographic region falls within the contiguous United States and generally implies a higher population density of both native and non-native peoples, as well as a strong institutional framework that provides physical access to markets and bureaucratic channels for negotiations. Tribal areas in the lower United States are unique, per their proximity to metropolitan centers and subsequent air, noise, and water pollutants. Continental native communities have a varied history with collective action; while there are innumerable cases of industry-indigenous relations to examine in the continental United States, the effective organization and negotiation tactics demonstrated by the Northern Ute Tribe of present-day Utah stand out.

A member of the Great Basin classification of Indigenous People, the Ute tribe was historically divided into many small nomadic bands that resided in the land around the Colorado Rockies and the high plateaus of southwestern United States. ${ }^{54}$ While eleven tribes are distinguished-six eastern and five western-only three of these tribes have settled on reservations: the 1500 members of the Southern Ute Tribe reside in present-day Colorado; the 2000 members of the Ute Mountain Tribe live in presentday Utah, New Mexico, and Colorado; and the 1970 members of the Northern Ute Tribe live in Utah, the tribe's namesake. ${ }^{55}$ Today, the Northern Ute Tribe is formally organized and federally recognized, with its headquarters located in Fort Duchesne, Utah on the Uintah and Ouray Reservation. Their reservation is the second-largest Indian Reservation in the United States, covering approximately 4.5 million acres of trust land. Included in these four million acres are 40,000 acres of oil, gas, tar sands, and oil shale. ${ }^{56}$

In the early 19th century, the Ute controlled about 23.5 million acres of land, which calculates as approximately 45 per cent of present-day Utah. ${ }^{57}$ After the Dawes Severalty Act of 1887-intended to more efficiently assimilate indigenous families into American culture-that landmass was reduced to four million acres. ${ }^{58}$ By 1930, that number had dwindled to about 350,000 acres. ${ }^{59}$ Under the Indian Reorganization Act of 1934 (also known as the Wheeler-Howard Act or the Indian New Deal), the United States government sought to dis-assimilate indigenous peoples throughout the continental United States by establishing Indian reservations, permitting tribal selfrule, and returning land and mineral rights to Native Americans. While many tribes successfully attained federal recognition in the years immediately following the Indian Reorganization Act, some tribes continue to struggle to gain the privileges associated with recognition. Perhaps thanks to its strong organizational structure-the Ute are recognized historically for their attention to communal living and political systems-, the Northern Ute Tribe began to repurchase its territory from the United States government in $1934 .{ }^{60}$

Between 1947 and 1955, the Northern Ute Tribe agreed upon large leases for the vast supply of oil and gas reserves on the Uintah and Ouray Reservation. By 1982, the Indian Mineral Development Act and the Federal Oil and Gas Royalty Management 


\section{A.M. Lerner et al.}

Act permitted tribes to enter into the "development and sale of mineral resources." While this meant that the tribe was susceptible to global fluctuations in oil prices and the American economy, they remained largely in control of the oil on their territory. By 1990, oil and gas generated approximately seven million dollars in annual revenue for the tribe. In 2000, the Department of Energy returned the Naval Oil Shale Reserve to the Northern Ute Tribe. ${ }^{62}$ By 2001, the tribe's annual revenue had jumped to 500 million dollars. ${ }^{63}$ In 1987, the Department of Energy "transferred the [undeveloped] Naval Oil Shale Reserves to the Northern Ute Tribe." 64

Driven by the successful extractions and energy leases of the late 19th century, in conjunction with the awareness that oil and gas are nonrenewable and therefore unsustainable resources and sources of revenue, the Northern Ute Tribe joined the Council of Energy Resource Tribes (CERT). CERT is a consortium of Native American tribes that helps reservations to consolidate their control and protest against unfair extractive projects. Through CERT, the Northern Ute Tribe was able to aggregate its interests with other tribes in negotiations with multinational corporations. ${ }^{65}$

However, CERT was not able to help the Northern Ute Tribe diversify its holdings and keep track of its expenses. In 2002, without a tax base or a business plan, the Northern Ute nearly went bankrupt. The tribe bounced back by selling off its oil and gas resources, collecting water settlement funds, investing in education, and bundling sales revenue into the creation of the high-tech, fully-integrated Ute Energy oil and gas company in 2005. By 2006, the tribe developed and leased nearly 300,000 acres of resource-rich land to oil and gas corporations. ${ }^{66}$ The Ute Energy oil company conducts all of its own exploratory projects and produced 60 wells between 2002 and 2006. The tribe's complete takeover of its right to negotiate over its own resources is historic. Today, the Northern Ute Tribe is the fourth-largest producer of oil in the region with two billion in annual revenue and a AAA bond rating. ${ }^{67}$ Learning from its mistakes, the Northern Ute Tribe invested 80 million USD in extractive exploration in 2007. While oil companies initially disliked the "new, assertive Ute tribe" of post 2002, they continue to engage the Ute Energy oil company as a valuable business partner. ${ }^{68}$

In conclusion: while indigenous herders and hunters struggle to find employment and durability in traditional indigenous areas like the Khanty-Mansiysk Autonomous Region, the Northern Ute have effectively learned to monetize the natural resources on their land in a way that supports its large reservation while respecting its sacred sites. From this case, scholars have concluded that a well-organized indigenous actor is capable of negotiating on its own behalf. However, it is important to recognize that much of the Northern Ute Tribe's bargaining capacity comes from the institutional framework designed by the Indian Reorganization Act of 1934, the Indian Mineral Development Act and the Federal Oil and Gas Royalty Management Act of 1982, and the decision of the US Department of Energy to sell the Naval Oil Shale Reserve to the Northern Ute Tribe in 2000. Therefore, the takeaway seems to be that the responsibility for creating supportive frameworks in which actors can effectively bargain must lie with an empowered, neutral, and objective third-party actor, such as the state or the international community. 


\subsubsection{Region four: Remote US}

Conflict between indigenous and industrial actors is often rooted in different understandings of land rights. In the United States, treaties made by Western colonists with local tribes were often based on linguistic and cultural misunderstandings of property. As settlers moved across the country to fulfill the nation's 'manifest destiny' and to reach the Pacific Coast, treaties increasingly became tools for displacement backed by military pressure, and lost any meaningful resemblance to an agreement made between equal parties. ${ }^{69}$ Early heritage laws in the United States continued to reflect Western notions of private property, which made it difficult to protect sites of value to indigenous peoples, like natural landscapes, or sites that mixed natural and cultural significance. These laws were also designed to protect private property owners from federal action, and could not legally accommodate many industry-indigenous scenarios in which an entire group of people seeks to protect property (whether private or public) from private action. With such a well-established history of injustice, Native Alaskans have come to expect little from the US government, particularly where the protection of culture is concerned.

Cases of indigenous-industry heritage protection conflict in Alaska highlight the shortcomings of historic preservation regulations that still struggle to accommodate indigenous cultural properties. Section 106 is a landmark piece of legislation passed as part of the 1966 National Historic Preservation Act (NHPA). It requires federal agencies to "take into account the effects of their undertakings" on historic resources in a transparent and accountable manner, although the regulations do not ultimately require preservation. The review process involves identifying and researching historic resources potentially affected, determining effects on these identified resources (whether sites are on the National Register of Historic Places or may be eligible in the future), exploring measures to avoid or reduce negative effects, and reaching an agreement with the State Historic Preservation Office (SHPO) or, in the case of indigenous groups, the Tribal Historic Preservation Office. ${ }^{70}$

Several problems inherent to the current regulations hinder review processes intended to protect cultural heritage, particularly for indigenous groups. The federal and state agencies (including the State and Tribal Historic Preservation Offices) responsible for overseeing the studies and keeping them honest may also see themselves as being in the business of making projects go smoothly, and view compliance as merely a paperwork exercise. Systems of compliance are so esoteric and laden with jargon that they are almost totally inaccessible to the public, resulting in few real opportunities for tribal advocates to negotiate with project proponents before serious problems arise. Pro forma public comment and public hearings are substituted for meaningful conversation with concerned parties. Perhaps this kind of 'black box' negotiation made sense when the review process was developed half a century ago, when agencies and project proponents did not have access to as much expertise and there were fewer groups equipped to contribute to heritage management decisions. ${ }^{71}$ However, the state of heritage law in the United States today leaves indigenous groups ill equipped to address private industry actions. 


\section{A.M. Lerner et al.}

The Trans-Alaska Pipeline controversy, which dragged on for years after the 1968 discovery of oil fields in Prudhoe Bay, ${ }^{72}$ is a prime example of the challenges facing indigenous land claims in the face of extractive industries. With more untapped oil than reserves in Texas, engineers from top energy companies rushed to plan a pipeline that would make Alaska's oil wealth accessible to the mainland United States. By early 1969, the Trans-Alaska Pipeline System (TAPS) announced an 800mile pipeline from Prudhoe Bay above the Arctic Circle to Valdez on Alaska's southern coast, cutting across federal, state, and private properties. Due to federal support, the project was obligated to undergo review under Section 106 and the National Environmental Policy Act (NEPA). Natives and environmental activists stridently opposed the pipeline, which cut across native hunting and fishing grounds and national forests (ostensibly created to protect nature from industrial incursion).

In 1970, five native villages in Alaska brought a lawsuit against both the private oil companies and the federal Department of the Interior. They demanded that construction be delayed until tribes could consult and provide their consent (a month later, environmental groups also sued the oil companies and Department of the interior on the grounds that the pipeline violated the National Environmental Protection Act). Both NEPA and Section 106 required an Environmental Impact Statement (EIS) for the proposed pipeline, which would also consider alternatives to reduce negative impacts. Native groups and environmentalists argued that the limited EIS was inadequate. ${ }^{73}$ Using NEPA, environmental groups won an injunction and work on the pipeline was stalled in order to complete more thorough assessments and negotiations with tribal groups. To hasten the process, in 1971 Nixon created the Alaska Native Claims Settlement Act (NASCA), which (arguably) addressed native claims to 44 million acres of land, which had gone unresolved for over a hundred years after American acquisition of the Alaska territory in 1867. NASCA also provided a cash settlement of nearly $\$ 1$ billion to tribal members. ${ }^{74}$

The next year, in 1972, the Department of the Interior released the final Environmental Impact Study-which had expanded dramatically from the original 256 pages to a nine-volume comprehensive assessment of the environmental and economic impact of the pipeline. ${ }^{75}$ After a 45 -day review period, the pipeline was approved. Environmental and indigenous groups (some of which were dissatisfied with NASCA) attempted to appeal. In 1973, the appeals court overturned approval for the pipeline, only to have Congress step in. In a close vote of 50 to 49, the Senate narrowly passed an amendment to national environmental law, effectively creating an exception for the pipeline and declaring that the Department of Interior had fulfilled the requirements of NEPA. Momentum for further opposition dwindled with the Arab oil embargo, which led to a spike in oil prices. Nixon signed the Trans-Alaska Pipeline Authorization Act, setting a precedent to table indigenous land rights and environmental debate in the interest of energy independence.

While Alaska Natives were ultimately unable to stop the pipeline, they did influence the way that Environmental Impact Assessments are conducted, and along the way, created a blueprint for how indigenous communities can fight against other extractive projects, including the recent Keystone XL pipeline. 


\section{Case analysis and policy implications}

In this paper, we identify four very different cases of indigenous-industry relations. In Tyumen Region, one of Russia's largest oil-producing territories, indigenous interests are largely protected by federal, regional, and local legislation. Although occasional legal and even violent rifts occur, the region seems to make efforts to integrate indigenous communities into preliminary negotiations, but also-more broadly-into other sectors like the educational system. Likewise, in Sakhalin, indigenous minorities are able to successfully negotiate with industrial actors because of institutional mechanisms, such as SIMDP and SIMDP-2. This process could be further improved with an expansion of institutional capacity, which requires the compliance of the regional government. By ensuring that governing actors adequately monitor industryindigenous relations in their jurisdiction, third-party bodies like the state or the international community could create better conditions regarding extractive projects.

Meanwhile, in the United States, a fair amount of variation remains in industryindigenous relations. While some indigenous communities-such as the sovereign and resource-rich Northern Ute Tribe, for example-are able to successfully bargain with industrial actors, other tribes-like those living on the extremely impoverished South Dakota Pine Ridge and Rose Bud Reservations-lack the resources and the organization to effectively negotiate for their collective interests. To the north, Alaska Natives may have been unsuccessful in their attempts to stop the pipeline, but they were able to influence institutional and policy-related changes that have impacted future negotiations. Surely, historical institutionalism is at play here; past successes (and failures) accrue and determine current actions, which, in turn, influence future behaviors and capabilities. Ultimately, it is this institutional growth over time that puts indigenous communities of the United States in a position to monetize their natural resources and bargain collectively. Supportive frameworks do not appear overnight, they instead take decades and even centuries to build and refine.

The United States and the Russian Federation, despite their numerous differences and geopolitical tensions, have much in common. In particular, both have numerous and sizable indigenous communities-some reports even claim that Native Americans share genetic material with indigenous Eurasians. ${ }^{76}$ Second, both nations possess ample natural resources, particularly oil and natural gas. Third, both nations currently regard the Arctic as the next frontier of resource extraction. In an age of conflict throughout the Middle East, these domestic resources can aid both nations in becoming self-sustaining with regard to energy use and production, thereby potentially leading to stronger national currencies, lower costs of living, and even higher domestic approval ratings. Considering these similarities, we understand that the barriers to successful industry-indigenous relations-including potential spills, violent protests, and failed negotiations-operate similarly in both Russia and the United States. In order to ensure strong negotiations on extraction projects and, in turn, to strengthen the economic and political nature of each state, federal authorities in both countries must become inextricably involved in ensuring that these negotiations are conducted in a fair and just manner. This also means that each 


\section{A.M. Lerner et al.}

state must commit to certain, shared international legislation-such as the UNDRIPthat protects indigenous communities and native lands from imperfect, dangerous, or depleting extractions.

This ability to work together, or at least in tandem, is important for a number of reasons. First, by collaborating on solutions, sharing best practices, or-at the leastholding domestic actors accountable to international law and norms, the United States and Russia can help set global standards for the treatment of native peoples with regard to extractive procedures. Second, these two countries can contribute their own lessons learned to nations throughout the developing world. By serving as leaders and mentors on resource extraction and indigenous rights for developing nations, Russia and the United States can contribute to the preservation of minority cultures, sacred lands, and indigenous traditions. Third, by sharing best practices or holding similar laws as just, the United States and Russia can demonstrate their commitment to international peace. Just as strong economic linkages across states can serve as a deterrent to conflict, ${ }^{77}$ shared or parallel practices regarding industry-indigenous relations-especially in their common Arctic region-can further bind together these two potentially conflictual states through their pursuit of shared objectives. Indeed, by promoting preliminary negotiations that comply with international law on extractive projects, the United States and Russia can demonstrate shared interests to the industry-indigenous actors, to their domestic populations, and to the international community. While shared interests and institutions might not completely quell the threat of international conflict, they can repair economic and legal relations between the two states and help boost public support for diplomatic engagement. We attest that these transnational efforts bode well-peacefully, even-for all of the actors involved.

The takeaways across these cases are as follows: first, negotiations are improved through collaboration and collapse when one actor diverges. Second, preliminary negotiations definitely lead to more successful operations, and this is increased when protective provisions are both institutionalized and monitored, usually by a thirdparty, identified as the state or the international community. We, therefore, suggest that the institutionalization of protections and the monitoring of participation will lead to more successful negotiations on extractive projects. In some cases, when a company provides financial benefits, the indigenous community may become benefits-addicted and therefore may no longer be interested in negotiating for autonomous authority and resource control. Neutral and objective third-party actors can mitigate this resource dependence by creating required extractive consultant positions held by indigenous representatives on all resource-based projects. In general, this will result in a shared burden, which may lead to more carefully negotiated contracts and extraction plans.

An indigenous actor is thought to benefit most from this kind of monitoring, as institutional frameworks such as the one proposed in this paper are understood to mitigate commitment problems in otherwise unequal negotiations. ${ }^{78}$ However, we argue that industrial actors can also reduce their long-term costs by engaging in short-term negotiations. It is possible that these two types of actors could engage in 
successful self-mediation without the assistance or monitoring of a third-party actor. However, the ideal negotiation process would be restrained by a system of checks and balances. And, considering that institutional bodies responsible for overseeing indigenous or energy-related issues already exist in both the US and Russian governments-indeed Article 3 of the aforementioned Federal Law 82-FZ specifically outlines the state's responsibility to ensure that extractive projects do not negatively affect indigenous peoples, their land, and their livelihood without good faith consultations, prior informed consent, and, if necessary, compensation ${ }^{79}$, it seems plausible that the monitoring of resource extractive conflicts could fall within their mandates. This includes not only equal industry and indigenous partners, but also an active state that can oversee negotiations from a neutral and just position. The state, in this case, would also be constrained by the system of international norms and rules that, theoretically, govern domestic behavior. Therefore, a clear chain of command would be in place to apply global legal regulations to non-state actors in domestic conflicts over resource extraction.

\section{Conclusion}

In this paper, we addressed the puzzle of why rational actors-indigenous communities or oil and gas corporations-fail to cooperate on extractive projects, even though strong collaborative agreements appear to favor both sides. By investigating a number of comparative cases of industry-indigenous conflict in both the United States and the Russian Federation, we demonstrate the positive benefits for both indigenous and industrial actors-though especially the former-in engaging in preliminary negotiations on extractive projects. However, these projects must be monitored by a neutral and objective third party - either in the form of a state or an international institution-in order to ensure that negotiations are reasonable and binding. By presenting this comprehensive analysis of both international law and domestic precedent in these two major northern states, we hope that our paper may serve as a guide for future collaborative efforts on extractive projects, especially as Russia and the United States begin to look toward the Arctic. Home to dozens of indigenous groups and untapped reserves of oil and gas, these states could mitigate potential conflicts in the Arctic by considering successful and unsuccessful historical models, as we have done in this paper. A strong partnership between industrial and indigenous actors could help to ensure not only the stability of extractive projects, but also the protection of indigenous groups from existential threats associated with territorial loss.

More broadly, our findings could easily translate beyond the resource extraction site to other scenarios of unbalanced actors. If heritage professionals wish to have a stake in preventing cultural injustices, a review process must be developed that values transparency and inclusivity as much as it does efficient compliance-otherwise, preservation has become a vain component of a bureaucratic exercise. Part of the solution is political: the status of indigenous communities in relation to their governments-and in their ability to conduct negotiations with private actors-must be 


\section{A.M. Lerner et al.}

more clearly and consistently defined. For indigenous groups that do not have collective legal title to their territory (as under the US reservation system), what special rights do those groups have to the land and to the cultural resources therein? Other helpful steps are largely procedural, and will hinge on efficient communication and coordination between stakeholders, agencies, and project proponents. Indigenous individuals-who may hold differing or even conflicting ideas about what constitutes a fair deal with state or industrial actors-and industrial actors must have the opportunity to provide meaningful input early on in the review process, and long before a project is implemented on the ground. Furthermore, a neutral and objective third-party supervisor-whether in the form of a state or an international body-is necessary in ensuring that both indigenous communities and industrial actors engage in fair and reasonable negotiations. These findings-highlighting both the importance of autonomous negotiating positions and third-party monitoringoffer important insights for community-corporate relations, not only in the Arctic, but worldwide. Continuing to negotiate the balance between inclusivity and efficient decision-making in the shadow of existential threat may be an intimidating proposal, but it is also arguably a preservationist and a political leader's most important work in promoting a just society and diverse heritage for both the present and the future.

\section{NOTES}

1. We wish to thank Ruslan Garipov of American University, Kazan Federal University, and Homer Law (a firm that focuses on indigenous law), for the many hours that he took reading and rereading drafts of this paper. His vast knowledge about both the Russian and US cases and his helpful feedback were critical to the success of this project. We also wish to thank the 2015-2016 Stanford University US-Russia Forum leadership team and two anonymous reviewers who gave us careful and thoughtful feedback on our paper. Finally, we wish to thank the many individuals who agreed to be interviewed for this project, including representatives from RosNeft, Chevron Oil and Gas, the Indigenous Peoples of the North (KEDR), the US Department of the Interior, the Tyumen Region Department of Ethnic Policy, and the Institute of Northern Development. This paper was originally prepared for the Stanford University US-Russia Forum in the spring of 2016.

2. Maria Favorsky, "The old man and the sea of oil," Greenpeace Canada, 18 August 2015.

3. Daria Litvinova, "Russian Shaman Battles Oil Giant Over 'Sacred Lake," The Moscow Times, 18 August 2015.

4. Daria Litvinova, "Russia: Guardian of Khanty Sacred Lake Facing Prison for Defending Himself against Stray Dogs Brought in by Oil Workers," International Work Group for Indigenous Affairs (IWGIA), 18 August 2015; "In Ugra, a Scandal around the Cult of Aboriginal Place," Center for Support of Indigenous Peoples of the North (CSIP), 17 June 2015.

5. Favorsky, "The old man and the sea of oil."

6. Sakirko, Elena. Personal Communication. 2017.

7. Mattias Ahren, "International Human Rights Law Relevant to Natural Resource Extraction in Indigenous Territories-An Overview," Nordic Environmental Law fournal 1 (2014); Susann Skogvang, "Extraction Industries in the North: What about Environmental Law and Indigenous Peoples' Rights?" Nordic Environmental Law fournal 1 (2014).

8. Ciaran O'Faircheallaigh, "Extractive Industries and Indigenous Peoples: a Changing Dynamic?" Fournal of Rural Studies 30 (2013); Natalia Yakolevleva, "Oil Pipeline Construction in Eastern Siberia: Implications for Indigenous people,” Geoforum 42, 6 (2011); 
Ingvild Ulrikke Jakobsen, "Extractive Industries in Arctic: The International Legal Framework for the Protection of the Environment," Nordic Environmental Law fournal 1 (2014).

9. Skogvang, "Extracting Industries in the North: What about Environmental Law and Indigenous Peoples' Rights?”; O’Faircheallaigh, "Extractive Industries and Indigenous Peoples: a Changing Dynamic?"; Ciaran O'Faircheallaigh et al., Earth Matters: Indigenous Peoples, the Extractive Industries, and Corporate Social Responsibility (Sheffield: Greenleaf Publishing, 2008).

10. Julie Rowland, “The New Legal Context of Indigenous Peoples' Rights: The UN Declaration on the Rights of Indigenous Peoples," American Indian Culture and Research Fournal 37, 4 (2013); Ruslan Garipov, "Extractive Industries and Indigenous Minority Peoples' Rights in Russia," Nordisk Milijorattslig Tidskrift (2014); Skogvang, "Extraction Industries in the North: What about Environmental Law and Indigenous Peoples' Rights?"

11. М. Ю. Мартынов, “Народы ханты и манси в условиях техногенной цивилизации," Социологически исследования 10 (2000). (M. Y. Martinov, "Khanty and Mansi peoples in a technological civilization," Sociological Research 10 (2000).)

12. Ahren, "International Human Rights Law Relevant to Natural Resource Extraction in Indigenous Territories-An Overview;" Mancur Olson, The Logic of Collective Action (Cambridge: Harvard University Press, 1965).

13. Chevron, Personal Interview, 2015; Rosneft, Personal Interview, 2015; Indigenous Peoples of the North, Personal Interview, 2015; See also: Joe Linklater and Sandra Newman, "The Arctic and Energy: Exploration and Exploitation Issues: Indigenous Peoples and Industry," Canada-United States Law fournal 30 (2004).

14. Г. Гулдин, “Антропологи как культурные брокеры: пример Сахалина," Этнографическое обозрение 3 (2008). (G. Golden, "Anthropologists as Cultural Brokers: The Example of Sakhalin,” Ethnographic Review 3 (2008).); Т. П. Роон “Размышление о Сахалине и его жителях в свете транснациональных проектов добычи углеводородов на шельфе Охотского моря," Этнографическое обозрение 3 (2008). (Т. P. Roon, "Reflection on Sakhalin Island and its inhabitants in the light of transnational projects of hydrocarbon production on the shelf of the Sea of Okhotsk," Ethnographic Review 3, (2008).)

15. For example: Ahren, "International Human Rights Law Relevant to Natural Resource Extraction in Indigenous Territories-An Overview;" Brenden Tobin, Indigenous Peoples, Customary Law and Human Rights: Why Living Law Matters (Oxford: Routledge, 2014). Jakobsen, "Extractive Industries in Arctic: The International Legal Framework for the Protection of the Environment;" Jean-Sebastien Boutet, "Opening Ungava to Industry: a Decentring Approach to Indigenous History in Subarctic Quebec, 1937-1954," Cultural Geographies 21, 1 (2014).

16. Elinor Ostrom. "Polycentric systems for coping with collective action and global environmental change," Global Environmental Change 20 (2010), 550.

17. Robert Keohane, "International Institutions: Two Approaches," International Studies Quarterly 32, 4 (December 1988); Douglass North, Institutions, Institutional Change, and Economic Performance, (Cambridge: Cambridge University Press, 1990).

18. Michael Wheeler, "Negotiation Analysis: An Introduction," Harvard Business School, 13 June 2002.

19. Lee Ross and Constance Stillinger, "Barriers to Conflict Resolution," Negotiation fournal (1991): 391, 396.

20. Wheeler, 2002, 12.

21. Max H. Bazerman, Ann Tenbrunsel, and Kimberly Wade-Benzoni, "When 'Sacred' Issues are at Stake," Negotiation fournal (January 2008): 113. Also James Fearon, "Rationalist Explanations for War," International Organization 49 (1995): 379-414. 
22. Howard Raiffa, The Art and Science of Negotiation, Cambridge: Harvard University Press, 1982, 24.

23. Ross and Stillinger, 1991, 400.

24. The authors use the terms Russian Federation and Russia synonymously throughout this paper.

25. General Assembly Resolution 61/295. United Nations Declaration on the Rights of the Indigenous People: Resolution Adopted by the General Assembly, A/61/L. 67 and Add.1 (13 September 2007), Available from http://www.un.org/esa/socdev/unpfii/documents/DRIPS_en.pdf.

26. Ibid.

27. United Nations, "Special Rapporteur Highlights 'Negative, Even Catastrophic' Impact of Extractive Industries on Rights of Indigenous Peoples, in Third Committee Statement," Press Release, United Nations Sixty-Sixth General Assembly, Third Committee, 19th and 20th Meetings, 17 October 2011. Available from http://www.un.org/press/en/2011/ gashc4013.doc.htm.

28. United Nations, "Special Rapporteur Highlights 'Negative, Even Catastrophic' Impact of Extractive Industries on Rights of Indigenous Peoples, in Third Committee Statement."

29. United Nations, "General Assembly Adopts Declaration on Rights of Indigenous Peoples; 'Major Step Forward' Towards Human Rights for All, says President," United Nations General Assembly Press Release, 107th and 108th Meetings, 13 September 2007. Available from http://www.un.org/press/en/2007/ga10612.doc.htm.

30. The Constitution of the Russian Federation, Article 69, (12 December 1993). Available from http://www.constitution.ru/en/10003000-01.htm.

31. Federica Prina, "Protecting the Rights of Minorities and Indigenous Peoples in the Russian Federation: Challenges and Ways Forward," Minority Rights Group Europe Report, 2014.

32. "Russian Association of Indigenous Peoples of the North (RAIPON)," Arctic-Council.org, 7 May 2015, Accessed on 7 March 2017.

33. Russian Association of Indigenous Peoples of the North (RAIPON), Accessed 7 March 2017. Available from http://raipon.info/activity/obshhaja-informacija.php

34. "Concluding Observations of the Committee on the Elimination of Racial Discrimination CERD/C/RUS/CO/19 20 August 2008," United Nations International Convention on the Elimination of all Forms of Racial Discrimination, 20 August 2008.

35. Federal Act 82-FZ, The Constitution of the Russian Federation, 30 April 1999. Available from http://constitution.garant.ru/act/right/180406.

36. Dmitry Berezhkov, "Why the Russian Government Shuts Down RAIPON," International Work Group for Indigenous Affairs, 28 November 2012, Accessed on 7 March 2017. Available from http://www.iwgia.org/news/search-news?news_id=710.

37. "Russia Signs Exploration Deal with Exxon," Al fazeera, 14 February 2013, Accessed 7 March 2017. Available from http://www.aljazeera.com/news/europe/2013/02/201321323958175681. html.

38. Pavel Sulyandziga, "RAIPON Statement," Arctic Council, 15 May 2013, Accessed 7 March 2017. Available from https:/oaarchive.arctic-council.org/bitstream/handle/11374/ 1569/ACMM08_Kiruna_2013_Statement_RAIPON_Rodion_Sulyandziga_English.pdf? sequence $=14 \&$ is Allowed $=\mathrm{y}$.

39. "Gregory Ledkov is Elected New Leader of RAIPON," UArctic, 1 April 2013, Accessed 7 March 2017. Available from http://www.uarctic.org/news/2013/4/gregory-ledkov-iselected-new-leader-of-raipon/.

40. Indigenous Peoples of the North, Personal Interview, Tyumen, 2015.

41. Jon Letman, "Indigenous Leaders Prevented from Leaving Russia," Al fazeera, 25 September 2014, Accessed 7 March 2017. Available from http://america.aljazeera.com/ articles/2014/9/25/russian-indigenousrepspreventedfromleavingcountry.html. 
42. Trude Petterson, “One More Indigenous Peoples' Organization Declared 'Foreign Agent,", The Barent Observer, 15 March 2016, Accessed 7 March 2017. Available from https:// thebarentsobserver.com/en/society/2016/03/one-more-indigenous-organization-declaredforeign-agent.

43. Constitutional Court of the Russian Federation, "On the Case on the Constitutionality of Provisions of Article 1 of the Federal Law: Decision of the Constitutional Court of the Russian Federation from 14.07.2015 N 21-P,” Press Release, 19 April 2016. Available from https://www.consultant.ru/law/hotdocs/43697.html.

44. Ruslan Garipov, Personal Interview, 11 February 2016.

45. James Anaya, "USA/ Indigenous peoples: 'New Measures Needed for Reconciliation and to Address Historical Wrongs," Former United Nations Special Rapporteur on the Rights of Indigenous Peoples, 11 September 2012. Available from http://unsr.jamesanaya.org/statements/ usa-indigenous-peoples-new-measures-needed-for-reconciliation-and-to-address-historicalwrongs.

46. Carey L. Biron, “U.N. Report Chastises U.S. for Status of Native Population,” Interpress Service News Agency, 20 September 2012, Accessed 12 March 2017. Available from http:// www.ipsnews.net/2012/09/u-n-report-chastises-u-s-for-status-of-native-population/.

47. Ibid.

48. Ministry of Regional Development of the Russian Federation, "Report of the Russian Federation on the Implementation of Provisions of the Framework Convention for the Protection of National Minorities," Second Report Submitted by the Russian Federation Pursuant to Article 25, Paragraph 2 of the Framework Convention for the Protection of National Minorities, 26 April 2005. Available from https://www.coe.int/t/dghl/monitoring/minorities/ 3_FCNMdocs/PDF_2nd_SR_RussianFederation_en.pdf.

49. On the Guarantees of the Rights of Indigenous Peoples of the Russian Federation, Public Law 256-F3, Russian Federal Laws, 8 July 2015. Available from: http://pravo.gov.ru/proxy/ips/? docbody $=\&$ prevDoc $=102059473 \&$ backlink $=1 \& \&$ nd $=102376016$

50. Rosneft, Personal Interview. Tyumen, Russian Federation, September 2015.

51. Rosneft Public Joint Stock Company, 2015 Annual Report, Page 180. Available from: https://www.rosneft.com/upload/site1/attach/0/04/a_report_2015_eng.pdf.

52. Rosneft, Personal Interview. Tyumen, Russian Federation, September 2015 and Indigenous Peoples of the North, Personal Interview, Tyumen, 2015.

53. Indigenous Peoples of Russia: Country Profile. World Bank Report, 2014, Washington, DC. Available from: http://documents.worldbank.org/curated/en/537061468059052611/Indigenouspeoples-of-Russia-country-profile

54. Azevedo, Warren L. "Handbook of North American Indians: Great Basin." Smithsonian Institution, Washington, D.C. 1986: 336. Also Barton, John D. "A history of Duchesne County." 1998, 39.

55. Ute Indian Tribe, Web. Accessed: 5 Mar. 2016. Available from: UteTribe.com.

56. Kinkead, Lucinda, and Dennis Romboy. "Utes Thriving after Nearly Going Broke.” Deseret News. 24 Sept. 2006.

57. Azevedo, 1986: 357.

58. Ibid., 356.

59. Ibid., 356.

60. Azevedo, 1986: 340, 353.

61. “30 US Code $\int 1701$ - Congressional Statement of Findings and Purposes." Legal Information Institute. Cornell University Law School, 12 Jan. 1983; Indian Mineral Development Act of 1982 (IMDA) 25 USC. Secs. 2101-2108.

62. “Naval Petroleum Reserves." Naval Petroleum Reserves. United States Department of Energy, 30 Jan. 2015. 


\section{A.M. Lerner et al.}

63. Azevedo, 1986: 363; Kinkead and Romboy, 2006.

64. Epstein, Lita, C.D. Jaco, and Julianne Iwersen-Niemann. "The Complete Idiot's Guide to the Politics of Oil.” Penguin Group, 2003: 136.

65. Azevedo, 1986: 580.

66. Kinkead and Romboy, 2006; Ute Energy. "Northern Ute Indian Tribe Announces Landmark, Multi-Million Dollar Energy Company.” PR Newswire. UBM Plc Company, 27 Oct. 2005.

67. Kinkead and Romboy, 2006.

68. Ibid.

69. Office of the Historian, "Indian Treaties and the Removal Act of 1830," Milestones, US Department of State. Available from: https:/history.state.gov/milestones/1830-1860/ indian-treaties

70. Advisory Council on Historic Preservation, "Case Digest: Section 106 in Action," Summer 2012.

71. Thomas King, Our Unprotected Heritage: Whitewashing the Destruction of Our Natural and Cultural Environment (Walnut Creek, CA: Left Coast Press, 2009).

72. Robert Klein et al., "Estimated Speculative Recoverable Resources of Oil and Natural Gas in Alaska," Alaska Department of Natural Resources, Division of Geological and Geophysical Surveys, January 1974. Available from: http://137.229.113.30/webpubs/dggs/ aof/text/aof044.pdf.

73. Alan Stone, "The Trans-Alaska Pipeline and Strict Liability for Oil Pollution Damage," Urban Law Annual; Fournal of Urban and Contemporary Law 9 (1975). Available from: http:// openscholarship.wustl.edu/law_urbanlaw/vol9/iss1/8

74. “Alaska Native Claims Settlement," 43 US Code Chapter 33. Available from: https://www. law.cornell.edu/uscode/text/43/chapter-33

75. Timothy Haab, et al., Environmental and Natural Resource Economics: An Encyclopedia (Santa Barbara, California: Greenwood, 2014).

76. Brian Handwerk, "Great Surprise: Native Americans Have West Eurasian Origins," National Geographic, National Geographic Society, 22 Nov. 2013.

77. Steven Levitsky and Lucan A. Way, "Linkage Versus Leverage: Rethinking the International Dimension of Regime Change," Comparative Politics 38.4 (2006).

78. Beatriz Magaloni, "Credible Power-Sharing and the Longevity of Authoritarian Rule," Comparative Political Studies 41, 4-5 (April 2008).

79. Federal Act 82-FZ, dated 30 April 1999 "O garantijah prav korennyh malochislennyh narodov Rossijskoj Federacii”, http://constitution.garant.ru/act/right/180406/, Article 3. Also A/HRC/15/37/Add.5, para 83.

\section{Bibliography}

“25 CFR 225.1 - Purpose and Scope,” Indian Mineral Development Act of 1982 (IMDA) 25 U.S.C. Secs. 2101-2108. Legal Information Institute. Cornell University Law School (1982). https://www.law.cornell. $\mathrm{edu} / \mathrm{cfr} / \mathrm{text} / 25 / 225.1$.

“30 US Code $\int 1701$ - Congressional Statement of Findings and Purposes." Legal Information Institute. Cornell University Law School, 12 January 1983. https://www.law.cornell.edu/uscode/text/30/1701 ?qtus_code_temp_noupdates=3\#qt-us_code_temp_noupdates.

“43 US Code Chapter 33 \ Alaska Native Claims Settlement.” Legal Information Institute. Cornell University Law School (Date Unspecified). https://www.law.cornell.edu/uscode/text/43/chapter-33

Advisory Council on Historic Preservation, "Case Digest: Section 106 in Action," Summer 2009. http:// cdm16064.contentdm.oclc.org/cdm/ref/collection/p266901 coll4/id/2445.

Ahren, Mattias, "International Human Rights Law Relevant to Natural Resource Extraction in Indigenous Territories-An Overview,” Nordic Environmental Law fournal, Issue 1 (2014): 21-37. http://nordiskmiljoratt. se/onewebmedia/Ahren\%20NMT\%202014-1.pdf. 


\section{Mitigating the Risks of Resource Extraction}

Anaya, James. "USA/ Indigenous peoples: 'New Measures Needed for Reconciliation and to Address Historical Wrongs.” Former United Nations Special Rapporteur on the Rights of Indigenous Peoples. 11 September 2012. Available from http:/unsr.jamesanaya.org/statements/usa-indigenous-peoples-new-measures-neededfor-reconciliation-and-to-address-historical-wrongs.

“Article 69 | The Federal Structure." The Constitution of the Russian Federation. 12 December 1993. http:// www.constitution.ru/en/10003000-04.htm.

Azevedo, Warren L. Handbook of North American Indians: Great Basin. Washington, D.C.: Smithsonian Institution, 1986.

Bazerman, Max H., Ann Tenbrunsel, and Kimberly Wade-Benzoni. "When 'Sacred' Issues are at Stake." Negotiation Fournal (January 2008): 113-117.

Berezhkov, Dmitry. "Why the Russian Government Shuts Down RAIPON." International Work Group for Indigenous Affairs. 28 November 2012. Accessed on 7 March 2017. http://www.iwgia.org/news/search-news? news_id=710.

Biron, Carey L. "U.N. Report Chastises U.S. for Status of Native Population.” Interpress Service News Agency. 20 September 2012. Accessed 12 March 2017. Available from http://www.ipsnews.net/2012/09/u-n-reportchastises-u-s-for-status-of-native-population/.

Boutet, Jean-Sebastien, "Opening Ungava to industry: a Decentring Approach to Indigenous History in Subarctic Quebec, 1937-1954,” Cultural Geographies 21, Issue 1 (2014): 79-97. http://journals.sagepub. com/doi/abs/10.1177/1474474012469761.

Chevron, Personal Interview, Moscow, 2015.

"Concluding Observations of the Committee on the Elimination of Racial Discrimination CERD/C/RUS/CO/19 20 August 2008," United Nations International Convention on the Elimination of all Forms of Racial Discrimination, 20 August 2008.

Constitutional Court of the Russian Federation, "On the Case on the Constitutionality of Provisions of Article 1 of the Federal Law: Decision of the Constitutional Court of the Russian Federation from 14.07.2015 N 21-P,” Press Release, 19 April 2016. https://www.consultant.ru/law/hotdocs/43697. html.

Epstein, Lita, C.D. Jaco, and Julianne Iwersen-Niemann. The Complete Idiot's Guide to the Politics of Oil. London: Penguin Group, 2003.

Favorsky, Maria. "The Old Man And The Sea Of Oil.” Greenpeace Canada. 2016. http://www.greenpeace.org/ canada/en/blog/Blogentry/the-old-man-and-the-sea-of-oil/blog/53847/.

Fearon, James. "Rationalist Explanations for War.” International Organization 49 (1995): 379-414.

Federal Act 82-FZ. The Constitution of the Russian Federation. 30 April 1999. http://constitution.garant.ru/ act/right/180406.

Garipov, Ruslan. "Extractive Industries and Indigenous Minority Peoples' Rights in Russia." Nordisk Milijorattslig Tidskrift (Nordic Environmental Law Journal) 1 (2014): 67-75. http://nordiskmiljoratt.se/ onewebmedia/Garipov\%20NMT\%202014-1.pdf.

Garipov, Ruslan. Personal Interview, 11 February 2016.

General Assembly Resolution 61/295. United Nations Declaration on the Rights of the Indigenous People: Resolution Adopted by the General Assembly, A/61/L.67 and Add.1 (13 September 2007). http://www.un.org/esa/ socdev/unpfii/documents/DRIPS_en.pdf.

Golden, G. “Anthropologists as Cultural Brokers: The Example of Sakhalin,” Ethnographic Review 3 (2008): 47-54. (Гулдин Г. “Антропологи как культурные брокеры: пример Сахалина.” Этнографическое обозрение 3 (2008): 47-54.

“Gregory Ledkov is Elected New Leader of RAIPON.” UArctic. 1 April 2013. Accessed 7 March 2017. Available from http:/www.uarctic.org/news/2013/4/gregory-ledkov-is-elected-new-leader-of-raipon/.

Haab, Timothy, et al. Environmental and Natural Resource Economics: An Encyclopedia. Westport: Greenwood Publishing Group, 2014.

Handwerk, Brian. “'Great Surprise': Native Americans Have West Eurasian Origins.” National Geographic. National Geographic Society, 22 Nov. 2013. http://news.nationalgeographic.com/news/2013/11/131120science-native-american-people-migration-siberia-genetics/.

Indigenous Peoples of Russia: Country Profile. World Bank Report. Washington, DC. 2014. http://documents. worldbank.org/curated/en/537061468059052611/Indigenous-peoples-of-Russia-country-profile

"In Ugra, a Scandal around the Cult of Aboriginal Place." Center for Support of Indigenous Peoples of the North (CSIP), 17 June 2015.

Indigenous Peoples of the North, Personal Interview, Tyumen, 2015. 


\section{A.M. Lerner et al.}

Jakobsen, Ingvild Ulrikke. "Extractive Industries in Arctic: The International Legal Framework for the Protection of the Environment." Nordisk Milijorattslig Tidskrift (Nordic Environmental Law Journal) 1 (2014): 39-52. http://nordiskmiljoratt.se/onewebmedia/Jakobsen\%20NMT\%202014-1.pdf.

Keohane, Robert. "International Institutions: Two Approaches." International Studies Quarterly 32, 4 (December 1988): 379-396. https://www.jstor.org/stable/2600589.

King, Thomas. Our Unprotected Heritage: Whitewashing the Destruction of Our Natural and Cultural Environment. Walnut Creek, CA: Left Coast Press, 2009.

Kinkead, Lucinda, and Dennis Romboy. "Utes Thriving after Nearly Going Broke.” Deseret News. 24 Sept. 2006. http://www.deseretnews.com/article/650192878/Utes-thriving-after-nearly-going-broke.html.

Klein, Robert, et al. "Estimated Speculative Recoverable Resources of Oil and Natural Gas in Alaska." Alaska Department of Natural Resources, Division of Geological and Geophysical Surveys, January 1974. http://137.229.113.30/webpubs/dggs/aof/text/aof044.pdf.

Letman, John. "Indigenous Leaders Prevented from Leaving Russia.” Al fazeera. 25 September 2014. Accessed 7 March 2017. Available from http://america.aljazeera.com/articles/2014/9/25/russianindigenousrepspreventedfromleavingcountry.html.

Levitsky, Steven, and Lucan A. Way. "Linkage Versus Leverage: Rethinking the International Dimension of Regime Change." Comparative Politics 38, 4 (2006): 379-400. https://www.jstor.org/stable/20434008? seq=1\#page_scan_tab_contents.

Linklater, Joe, and Sandra Newman. "The Arctic and Energy: Exploration and Exploitation Issues: Indigenous Peoples and Industry." Canada-United States Law fournal, 30 (2004): 301-305. http://scholarlycommons. law.case.edu $/$ cgi $/$ viewcontent.cgi? article $=1226 \&$ context $=$ cuslj.

Litvinova, Daria. "Russian Shaman Battles Oil Giant Over 'Sacred Lake.” The Moscow Times, 18 August 2015. https://themoscowtimes.com/articles/russian-shaman-battles-oil-giant-over-sacred-lake-49038.

—. "Russia: Guardian of Khanty Sacred Lake Facing Prison for Defending Himself against Stray Dogs Brought in by Oil Workers." International Work Group for Indigenous Affairs (IWGIA), 18 Aug. 2015. http:// www.iwgia.org/news/search-news?news_id=1232.

Magaloni, Beatriz. "Credible Power-Sharing and the Longevity of Authoritarian Rule." Comparative Political Studies 41, 4-5 (April 2008): 715-741.

Martinov, M. U. "Khanty and Mansi peoples in a technological civilization," Sociological Research 10 (2000): 64-65. http://ecsocman.hse.ru/data/502/890/1216/012.MARTYNOV.pdf. (М. Ю. Мартынов, “Народы ханты и манси в условиях техногенной цивилизации," Социологические исследования 10 (2000): 64-65.)

Ministry of Regional Development of the Russian Federation, "Report of the Russian Federation on the Implementation of Provisions of the Framework Convention for the Protection of National Minorities," Second Report Submitted by the Russian Federation Pursuant to Article 25, Paragraph 2 of the Framework Convention for the Protection of National Minorities, 26 April 2005. https://www.coe.int/t/dghl/monitoring/ minorities/3_FCNMdocs/PDF_2nd_SR_RussianFederation_en.pdf.

“Naval Petroleum Reserves.” United States Department of Energy, 30 Jan. 2015. https://energy.gov/fe/services/ petroleum-reserves/naval-petroleum-reserves.

North, Douglass. Institutions, Institutional Change, and Economic Performance, Cambridge: Cambridge University Press, 1990.

O'Faircheallaigh, Ciaran. "Extractive Industries and Indigenous Peoples: a Changing Dynamic?" fournal of Rural Studies 30, 2013: 20-30. http://solutions-network.org/site-fpic/files/2012/09/JRS-ExtractiveIndustriesC-OFaircheallaigh1.pdf.

Ciaran O'Faircheallaigh, et al. Earth Matters: Indigenous Peoples, the Extractive Industries, and Corporate Social Responsibility. Sheffield: Greenleaf Publishing, 2008.

Office of the Historian, "Indian Treaties and the Removal Act of 1830," Milestones, US Department of State. https://history.state.gov/milestones/1830-1860/indian-treaties

Olson, Mancur. The Logic of Collective Action. Cambridge: Harvard University Press, 1965.

On the Guarantees of the Rights of Indigenous Peoples of the Russian Federation, Public Law 256-F3, Russian Federal Laws, 8 July 2015. http://pravo.gov.ru/proxy/ips/?docbody=\&prevDoc=102059473\&backlink=1\& \&nd $=102376016$

Ostrom, Elinor. "Polycentric systems for coping with collective action and global environmental change." Global Environmental Change 20, (2010): 550-557.

Petterson, Trude. “One More Indigenous Peoples' Organization Declared 'Foreign Agent." The Barent Observer. 15 March 2016. Accessed 7 March 2017. Available from https://thebarentsobserver.com/en/ society/2016/03/one-more-indigenous-organization-declared-foreign-agent. 


\section{Mitigating the Risks of Resource Extraction}

Prina, Federica. "Protecting the Rights of Minorities and Indigenous Peoples in the Russian Federation: Challenges and Ways Forward.” Minority Rights Group Europe Report. 2014. http://minorityrights.org/ wp-content/uploads/2014/11/mrg-protecting-rights-minorities-indigenous-peoples-russian-federation_ English.pdf

Raiffa, Howard. The Art and Science of Negotiation. Cambridge: Harvard University Press. 1982.

Roon, T.P. "Reflection on Sakhalin Island and its inhabitants in the light of transnational projects of hydrocarbon production on the shelf of the Sea of Okhotsk," Ethnographic Review 3 (2008): 36-47. http:// journal.iea.ras.ru/archive/2000s/2008/Roon_\%202008_3.pdf. (Роон Т.П. “Размышление о Сахалине и его жителях в свете транснациональных проектов добычи углеводородов на шельфе Охотского моря,” Этнографическое обозрение 3 (2008): 36-47.)

Rosneft. Personal Interview, Tyumen. 2015.

Ross, Lee and Constance Stillinger. "Barriers to Conflict Resolution.” Negotiation fournal (1991): 389-404.

Rowland, Julie. “The New Legal Context of Indigenous Peoples' Rights: The UN Declaration on the Rights of Indigenous Peoples." American Indian Culture and Research Fournal 37, 4 (2013): 141-156. http:// uclajournals.org/doi/10.17953/aicr.37.4.g4566527x73h350x.

"Russia Signs Exploration Deal with Exxon." Al fazeera. 14 February 2013. Accessed 7 March 2017. http:// www.aljazeera.com/news/europe/2013/02/201321323958175681.html.

Russian Association of Indigenous Peoples of the North (RAIPON). Accessed 7 March 2017. http://raipon.info/ activity/obshhaja-informacija.php

"Russian Association of Indigenous Peoples of the North (RAIPON)." Arctic-Council.org. 7 May 2015. Accessed on 7 March 2017. http://www.arctic-council.org/index.php/en/about-us/permanent-participants/raipon

Sakirko, Elena. Personal Communications. 2017.

Skogvang, Susann. "Extraction Industries in the North: What about Environmental Law and Indigenous Peoples' Rights?” Nordisk Milijorattslig Tidskrift (Nordic Environmental Law Journal) 1 (2014): 13-19. http://nordiskmiljoratt.se/onewebmedia/Skogvang\%20NMT\%20\%202014-1.pdf.

"Stability, Technology, Development: Annual Report 2015." Rosneft Public Joint Stock Company. 2015. https://www.rosneft.com/upload/site2/document_file/a_report_2015_eng1.pdf.

Stone, Alan. "The Trans-Alaska Pipeline and Strict Liability for Oil Pollution Damage." Urban Law Annual; fournal of Urban and Contemporary Law 9 (1975): 179-201. http://openscholarship.wustl.edu/cgi/ viewcontent.cgi? article $=1706 \&$ context $=$ law_urbanlaw.

Sulyandziga, Pavel. "RAIPON Statement." Arctic Council. 15 May 2013. Accessed 7 March 2017. Available from https://oaarchive.arctic-council.org/bitstream/handle/11374/1569/ACMM08_Kiruna_2013_ Statement_RAIPON_Rodion_Sulyandziga_English.pdf?sequence=14\&isAllowed=y.

United Nations. "Special Rapporteur Highlights 'Negative, Even Catastrophic' Impact of Extractive Industries on Rights of Indigenous Peoples, in Third Committee Statement.” Press Release, United Nations SixtySixth General Assembly, Third Committee, 19th and 20th Meetings, 17 October 2011. http://www.un. org/press/en/2011/gashc4013.doc.htm.

—. "General Assembly Adopts Declaration on Rights of Indigenous Peoples; 'Major Step Forward' Towards Human Rights for All, says President.” United Nations General Assembly Press Release, 107th and 108th Meetings, 13 September 2007. http://www.un.org/press/en/2007/ga10612.doc.htm.

Ute Energy. "Northern Ute Indian Tribe Announces Landmark, Multi-Million Dollar Energy Company.” PR Newswire. 27 Oct. 2005. http://www.prnewswire.com/news-releases/northern-ute-indian-tribeannounces-landmark-multi-million-dollar-energy-company-55603122.html.

Ute Indian Tribe. Accessed: 5 Mar. 2016. http://www.UteTribe.com.

Wheeler, Michael. "Negotiation Analysis: An Introduction." Harvard Business School. 13 June 2002.

Yakolevleva, Natalia. "Oil Pipeline Construction in Eastern Siberia: Implications for Indigenous People." Geoforum 42, 6 (2011): 708-719. http://www.sciencedirect.com/science/article/pii/S0016718511000832. 